\title{
Short-time scale coupling between termohaline and meteorological forcing in the Ría de Pontevedra*
}

\author{
PAULA C. PARDO, MIGUEL GILCOTO and FIZ F. PÉREZ \\ Instituto de Investigacións Mariñas (CSIC), Eduardo Cabello 6, 36208 Vigo, Spain.
}

\begin{abstract}
SUMMARY: Two cruises were performed in May-June and October-November 1997 in the Ría de Pontevedra under strong downwelling conditions. Temperature and salinity data were recorded in short sampling periods to describe the changes in thermohaline property distribution in a short time scale. In order to obtain the residual fluxes in the Ría, a bi-dimensional non-stationary salt and thermal-energy weight averaged box-model was applied. Outputs from this kinematic model were compared with Upwelling Index, river flow and density gradient, resulting in a good multiple correlation, which proves the strong coupling between thermohaline properties and meteorological variability. Ekman forcing affects the whole area but mainly controls the dynamics of outer zones. The intensity of its effect on the circulation pattern within the Ría depends on the grade of stratification of the water bodies. River flow is more relevant in inner parts. According to estimated spatially averaged velocities, water residence time is lower than two weeks in outer parts of the Ría, and decreases toward the inner zones.
\end{abstract}

Key words: hydrography, box-model, Ekman transport, Rías Baixas (NW Spain).

\section{INTRODUCTION}

The Ría de Pontevedra is one of four ancient valleys submerged during the last glacial period, which are known as the Galician Rías Baixas. It is sited on the west Galician coast (NW Spain), located between $42.25^{\circ} \mathrm{N}$ and $42.45^{\circ} \mathrm{N}$ and $8.69^{\circ} \mathrm{W}$ and $8.85^{\circ} \mathrm{W}$ (Fig. 1). Lérez River discharges in this northeast-southwest orientated V-shaped Ría, with an annual average runoff of $21 \mathrm{~m}^{3} \mathrm{~s}^{-1}$. The Ons and Onza Islands delimit two mouths. The northern mouth has a maximum depth of $18 \mathrm{~m}$ and a width of $3.8 \mathrm{~km}$. The southern one is $7.7 \mathrm{~km}$ wide and $60 \mathrm{~m}$ deep at its central part. Even though there is an effluent from a paper production industry complex in its inner part (González-Quijano et al., 1991), fishing

\footnotetext{
*Received October 6, 1999. Accepted April 20, 2000.
}

resources and aquaculture are socially and economically important in this Ría.

The Ría de Pontevedra is a partially mixed estuary (Bowden, 1980) with a two-layer residual positive estuarine circulation (Pritchard, 1955). In a classical estuarine circulation pattern, coastal water flows in along the bottom, rises and mixes with the river flow and flows out along the surface (Fraga, 1981). In these latitudes the Coriolis effect forces the outwards current to go out along the north shore of the Ría and the inward current along the south one. This pattern can be greatly modified by the winds over the shelf, which are responsible for the upwelling events characterising the Galician west coast. Between spring and autumn, the Azores Anticyclone reaches its highest latitude, generating persistent northerly winds which intensify the surface outgoing of fresh water, introducing colder, nutrient- 
enriched bottom waters. The oceanic surface water

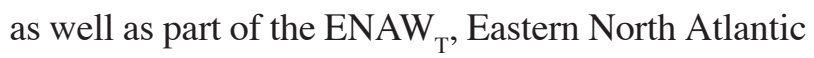
Central Water Tropical mode (Ríos et al., 1992), enter the Ría. When southerly winds prevail, the surface flow is piled up over the coast generating a front that keeps back the outflow of less dense waters, slowing the positive estuarine circulation or even reversing its direction (Álvarez-Salgado, 1993). In this kind of estuary, the effect of tidal prism is cancelled out when sampling covers time series longer than the tidal wave period (Pritchard, 1951).

The Rías located on the Galician coast have been intensively studied as being zones rich in fishing resources with a major dedication to aquaculture. The first cruises looking for approximations to evaluate the movement of the water bodies within these systems were carried out with long sampling intervals, varying from fifteen days (Mouriño et al., 1982; Ríos, 1992) to months (Prego et al., 1990). The resulting descriptions, of great value then, were proven to be inadequate in more recent studies (Álvarez-Salgado, 1993; Rosón et al., 1995). What characterises the Galician Rías Baixas from typical estuaries is that they are open systems with a major exchange with oceanic waters, so meteorological conditions over the shelf greatly affect the dynamics of the Ría in short time scales. Rosón et al. (1995) carried out their study in the Ría de Arousa with a sampling period of approximately two days a week. According to their results, the principal external forces controlling the internal dynamics of the Ría are the prevailing winds over the shelf, in addition to other conditions such as sea-atmosphere heat exchange or river flow. When shelf winds induce upwelling events, positive estuarine circulation is enhanced (Rosón et al., 1995). During strong downwelling conditions, water from the shelf entering the Ría causes the water inside it to be advected to the shelf through lower layers. In the present work, the strong control of Ekman transport in the circulation pattern of the Ría has also been demonstrated. A time variable front, which separates two opposite circulation patterns and is controlled by the prevailing shelf winds was also found.

The first attempts to evaluate the residual circulation of these systems were made by applying $2 \mathrm{D}$ stationary box-models using salinity as a tracer (Prego et al., 1990). Having long sampling intervals, box-model outputs did not allow the evaluation of more frequent wind-forced events in the Ría. Rosón et al. (1997), sampling two days a week in the Ría de Arousa, introduced the temperature as a new tracer as well as a non-stationary term. The resulting fluxes were averaged between thermohaline properties to obtain more realistic numerical estimations even on dates between sampling days. Outputs from this box-model showed that $50 \%$ of the variability of fluxes entering outer parts of the Ría can be estimated from the upwelling index, while 9 and $5 \%$ of the remaining variability are explained by heat exchange with the atmosphere and river flow respectively.

The aim of this paper is to characterise, on a short time scale, the coupling between thermohaline distributions within the Ría and the driving conditions to which it is subjected. To quantify this relation, a bi-dimensional non-stationary salt and thermal energy weight-averaged box-model was applied, on the basis of volume, salt and thermalenergy balances. In order to better evaluate the upwelling and downwelling effects on the circulation, the time variation of fluxes at different sites of the Ría was also taken into account.

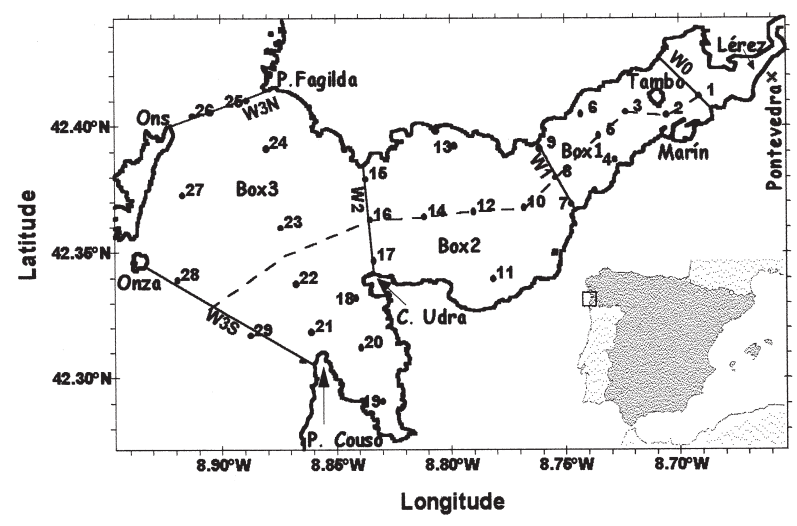

FIG. 1. - Ría de Pontevedra and measured stations. The dotted line corresponds to the longitudinal section. Box-model boxes are also shown.

\section{MATERIALS AND METHODS}

\section{Cruises}

Two cruises were made in 1997 , on board the oceanographic vessel Mytilus, which belongs to the Instituto de Investigacións Mariñas in Vigo (CSIC), and sampling was performed at 29 stations (Fig. 1). The first cruise was in spring, on 19, 22, 26 and 30 May and on 2 and 5 June. The second cruise was made on 22, 27 and 30 October and on 3 and 6 November. Two SBE-25 SEALOGGER CTDs were used to measure the thermohaline properties. The data were filtered by a low pass moving average filter. 
A meteorological station was sited on Ons Island to obtain the velocity and direction of winds. Winddriven horizontal transports in the surface Ekman layer were calculated (Fig. 2) as:

$$
W_{x}=\frac{-\rho_{a} C_{d} V V_{y}}{f \rho_{w}}\left(\mathrm{~m}^{2} \mathrm{~s}^{-1}\right)
$$

where $V$ is wind velocity $\left(\mathrm{m} \mathrm{s}^{-1}\right), V_{y}=$ north component of wind velocity $\left(\mathrm{m} \mathrm{s}^{-1}\right), \rho_{a}=$ air density $(1.22$ $\left.\mathrm{kg} \mathrm{m}^{-3}\right), \rho_{w}=$ water density $\left(1025 \mathrm{~kg} \mathrm{~m}^{-3}\right), C_{d}=$ empirical drag coefficient (0.0014) (Smith, 1988), and $f=2 \Omega \operatorname{sen} \lambda$ Coriolis factor $\left(f \sim 1.69 \cdot 10^{-6} \mathrm{~s}^{-1}, \Omega=\right.$ $7.29 \cdot 10^{-5} \mathrm{~s}^{-1}$ and $\lambda=42.35^{\circ}$ ). The classical Upwelling Index (water-volume transport per $\mathrm{km}$ of coast) is: $I_{w}=-1000 W_{x}$ (Bakun, 1973). Negative values of Ekman transport $\left(W_{x}\right)$ indicate upwelling conditions.

We lacked reliable gauging station data to estimate the input of fresh water from Lérez River, and we calculated it by applying the algorithm given by Ríos et al. (1992). Thus, we consider the neighbouring Oitabén River basin (edaphologically and meteorologically similar to the Lérez River basin) and rainfall data from the well located meteorological station of Peinador $(256 \mathrm{~m}$ high and $20 \mathrm{~km} \mathrm{SSE}$ from Station 1). The Lérez River flow was compared with one-day delayed rainfall data from the meteorological station of Lourizán (Marín), and showed a similar variation pattern $(r=0.6)$ (Fig. 2).

\section{Box-model}

A box-model similar to the one Rosón et al. (1997) made for the Ría de Arousa is developed here. The Ría de Pontevedra, with an area of 145 $\mathrm{km}^{2}$ and a length of $23 \mathrm{~km}$, was divided into three boxes (Fig. 1). The boxes' walls are made up of at least one sampling station and are placed between capes of opposite coasts. W3 represents the outer limit of the Ría and is composed of the northern mouth (W3N) and the southern mouth (W3S).

The assumed zero horizontal velocity depth $\left(Z_{c}\right)$ (Rosón et al., 1997) is determined by the depth of the mean density in each profile of the water column and separates all the walls and boxes into two halves. We thus introduce a low error in our system of equations. For example: considering a $1 \mathrm{~m}$ error in the depth of $Z_{c}$, the value of the horizontal fluxes changes by $5 \%$ and that of the vertical ones by $6 \%$.

Two systems of equations, one for each thermohaline property, are fitted into each half-box, consisting of volume and salt or thermal energy balances. Because there are wide ranges of temperature and salinity in the Ría, we consider thermal energy conservation and not temperature conservation. Water expansion and contraction is assumed to be negligible and the volume of a complete box does not vary with time (a mean tidal volume in the Ría is assumed). The equations for the upper half-box are thus:

Volume balance:

$$
Q_{n}^{N u}-Q_{n-1}^{N u}+Q_{z m}^{N}+Q_{r}+L-E=\frac{\partial V_{m}^{u}}{\partial t}
$$

Salt balance:

$$
\begin{gathered}
Q_{n}^{S u} \rho_{n}^{u} S_{n}^{u}-Q_{n+1}^{S u} \rho_{n+1}^{u} S_{n+1}^{u}+Q_{z m}^{S} \rho_{m}^{Z c} S_{m}^{Z c}+ \\
\quad+M_{m}^{u}\left(\rho_{m}^{b} S_{m}^{b}-\rho_{m}^{u} S_{m}^{u}\right)=\frac{\partial\left(V_{m}^{u} \rho_{m}^{u} S_{m}^{u}\right)}{\partial t}
\end{gathered}
$$

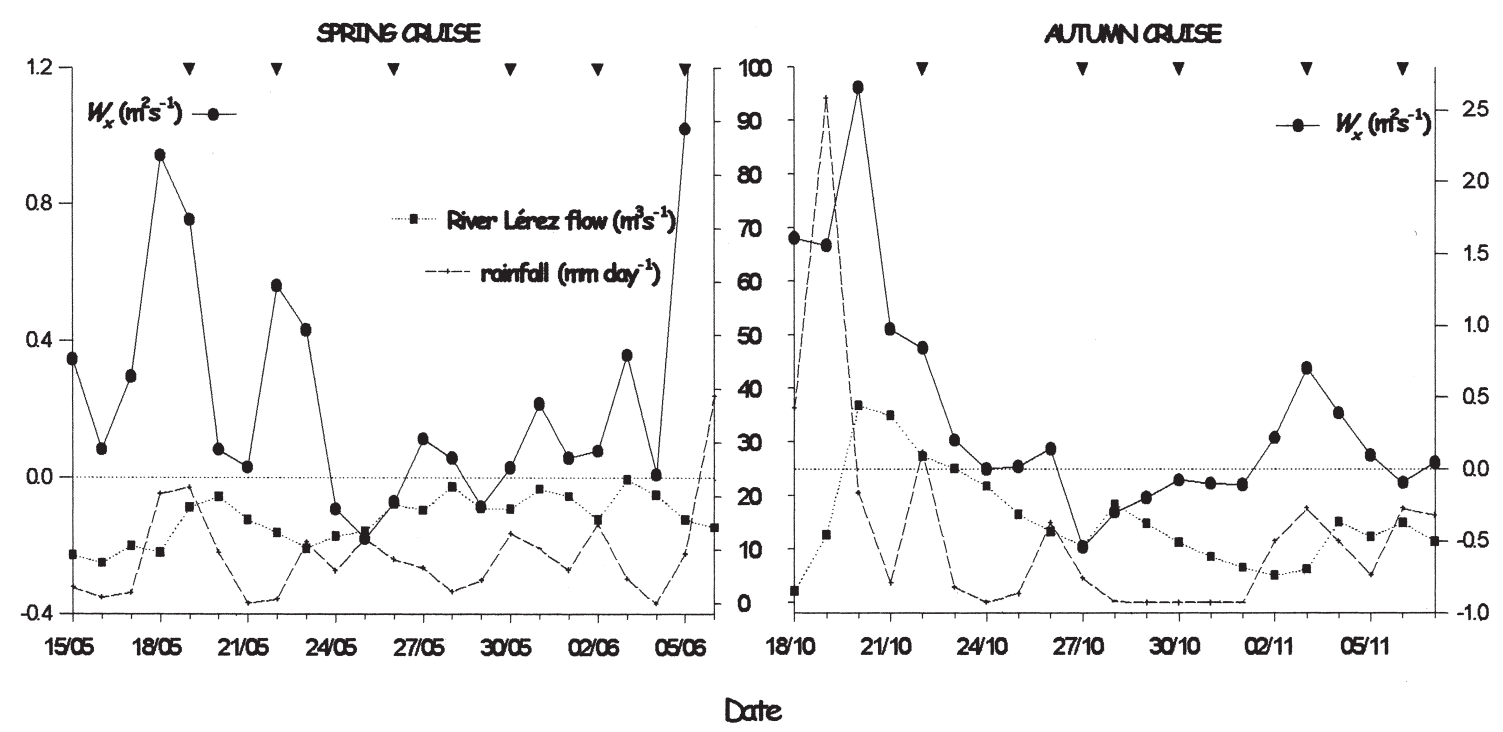

FIG. 2. - Ekman transport $\left(W_{x}\right)$, rainfall and Lérez River flow for both cruises. Triangles represent the sampling days. 
Thermal energy balance:

$$
\begin{gathered}
Q_{n}^{e u} \rho_{n}^{u} e_{n}^{u}-Q_{n+1}^{e u} \rho_{n+1}^{u} e_{n+1}^{u}+Q_{z m}^{e} \rho_{m}^{z c} S_{m}^{z c}+ \\
+M_{m}^{e}\left(\rho_{m}^{b} e_{m}^{b}-\rho_{m}^{u} e_{m}^{u}\right)+Q_{r} \rho^{a} e^{a}+L \rho^{a} e^{a}+ \\
+C q_{m}=\frac{\partial\left(V_{m}^{u} \rho_{m}^{u} e_{m}^{u}\right)}{\partial t}, \\
\frac{\partial V}{\partial t} \equiv V(t+1)-V(t), \\
\frac{\partial(V \rho N)}{\partial t} \equiv V(t+1) \rho(t+1) N(t+1)-V(t) \rho(t) N(t)
\end{gathered}
$$

where $u=$ upper half-box; $b=$ lower half-box; $Z_{c}=$ surface; $n=$ wall $(\mathrm{n}=0,1,2,3) ; m=$ box $(m=1,2,3)$; $t=$ date of calculated flux (days); $\Delta t=1$ day; $V=$ half-box volume $\left(\mathrm{m}^{3}\right) ; N=$ property in half-box or wall $(N=e, S) ; \rho=$ water density $\left(\mathrm{kg} \mathrm{m}^{-3}\right) ; \rho^{\mathrm{a}}=$ air density $\left(\mathrm{kg} \mathrm{m}^{-3}\right) ; e=T C_{p}$ thermal energy per mass $\left(\mathrm{J} \mathrm{kg}^{-1}\right) ; C_{p}=$ seawater specific heat at constant pressure $\left(\mathrm{J}^{p} \mathrm{~kg}^{-1}{ }^{\circ} \mathrm{C}^{-1}\right) ; C q=$ atmosphere-ocean heat exchange $\left(\mathrm{J} \mathrm{day}^{-1}\right)$ (sum of the heat lost by evaporation and reflexion, the exchange by conduction (Otto, 1975) and the long-wave back radiation lost by the sea (Pickard, 1990)); $L=$ rainfall $\left(\mathrm{m}^{3} \mathrm{~s}^{-1}\right) ; E$ = evaporation $\left(\mathrm{m}^{3} \mathrm{~s}^{-1}\right)$; and $Q_{r}=$ Lérez River flow $\left(\mathrm{m}^{3} \mathrm{~s}^{-1}\right)$.

For equations in the lower half-box $Q_{r}=C q=L$ $=E=0$, and vertical fluxes have the same value as in the upper half-box but an opposite sign. The calculated variables $\left(\mathrm{m}^{3} \mathrm{~s}^{-1}\right)$ (Fig. 3) are horizontal fluxes crossing each wall $\left(Q_{n}^{N u}, Q_{n}^{N b}, Q_{n+1}^{N u}, Q_{n+1}^{N b}\right)$, vertical ones $\left(Q_{z m}^{N}\right)$, and those corresponding to the

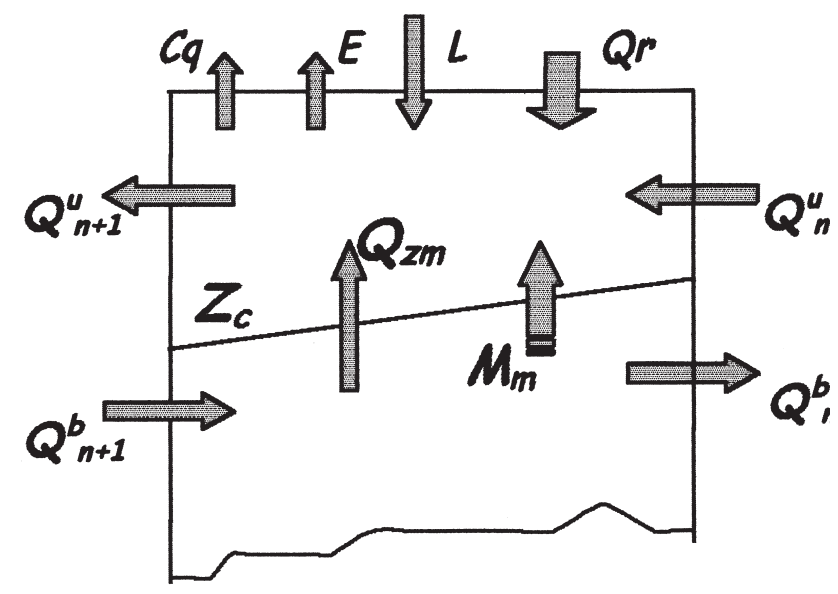

FIG. 3. - General box with considered fluxes. $E=$ evaporation; $L=$ rainfall; $Q_{r}=$ Lérez River flow; $Q^{u}{ }_{n}, Q^{u}{ }_{n+1}=$ upper half-box horizontal fluxes in walls $n$ (inner) and $n+1$ (outer); $Q^{b}, Q^{b}{ }_{n+1}=$ lower half-box horizontal fluxes in walls $n$ and $n+1 ; Q_{z m}=$ vertical flux in box $m ; M_{m}=$ mixing flux in box $m$. vertical mixing $\left(M_{m}^{N}\right)$. It results in 14 unknowns for each system of equations and 12 equations to solve them. Since 2 unknowns remain to solve each system, horizontal fluxes crossing W0 are imposed as boundary conditions. For this purpose, a new box is added, enclosing the volume from the opening of Lérez River until W0 (Fig. 1). From rainfall, evaporation flux, atmosphere-ocean heat exchange and Lérez River flow data, horizontal fluxes across each half of W0 $\left(Q_{0}^{N b}, Q_{0}^{N u}\right)$ are calculated in this pyramidal box.

Volume- and surface-averaged thermohaline properties in boxes, horizontal borders and walls are calculated after a three-dimensional square inverse distance interpolation. For the purpose of calculating the daily fluxes, a time cubic-spline interpolation is also made for thermohaline properties and half-box volumes. If we know the boundary conditions, we can extend each system of equations to all boxes, solving them by Gaussian elimination with complete pivoting (Burden and Faires, 1993).

Independently calculated thermal energy and salt fluxes are generally not equal. A weight-average factor is needed to calculate an averaged set of fluxes $\left(Q_{n}^{a v}, Q_{z m}^{a v}, Q_{m}^{a v}\right)$. These averaged fluxes are based on the minimisation of the thermohaline error cost function, related to the anomaly that exists when salt fluxes are calculated on the basis of thermal energy balance and vice versa. With the solution from this minimisation $(X)$ we establish a relation between the thermohaline fluxes and the averaged ones. $X$ is mainly controlled by salt and temperature vertical gradients $(\Delta T, \Delta S)$, so the property with the greatest gradient is the one whose fluxes take most of the weight in the average function (Rosón et al., 1997). The weight-average factor is modulated with a scale factor $(\varpi)$, which comes from the International Equation of State of Seawater 1980 (UNESCO, 1981):

$$
\begin{gathered}
\Delta T=T_{n}^{b}-T_{n}^{u}, \quad \Delta S=S_{n}^{b}-S_{n}^{u}, \quad \varpi=\frac{\frac{\partial \rho}{\partial S}(S, T, 0)}{\frac{\partial \rho}{\partial T}(S, T, 0)} \\
\mathrm{X}=\frac{(\Delta T)^{2}}{(\Delta S)^{2} \varpi^{2}+(\Delta T)^{2}}, \\
Q_{n}^{a v l}=Q_{n}^{S l}(1-\mathrm{X})+Q_{n}^{e l} \mathrm{X}, \quad l=u \text { or } b
\end{gathered}
$$

All fluxes are averaged in this way except vertical ones $\left(Q_{z m}^{a v}\right)$, which are calculated from the volume balance equation. 


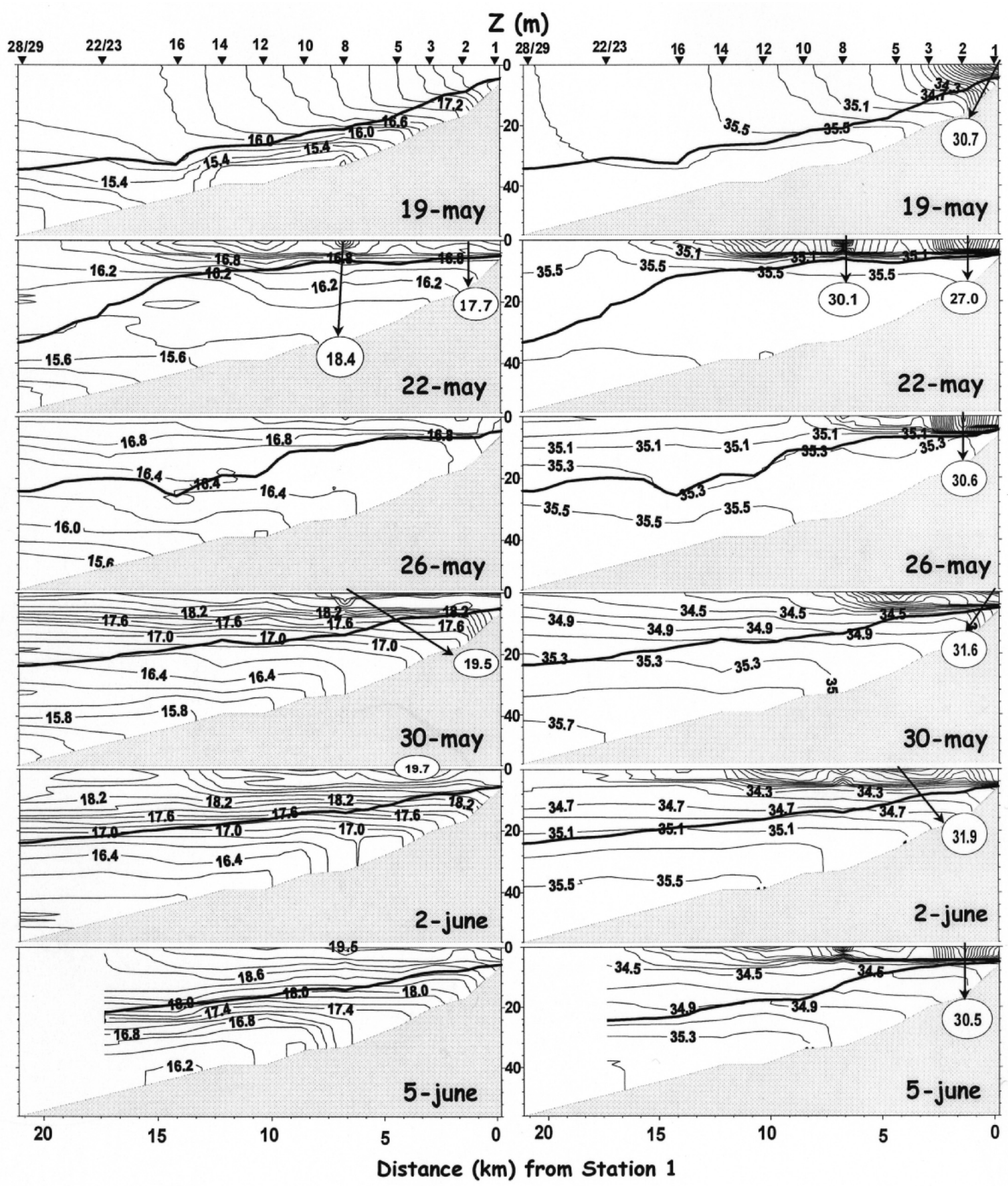

FIG. 4. - Thermohaline distributions for the spring cruise across a longitudinal section parallel to the Ría axis. Left figures show temperature $\left({ }^{\circ} \mathrm{C}\right)$ distributions and right ones show salinity distributions. The black line shows the position of $Z_{c}$ for each sampling day.

\section{THERMOHALINE DESCRIPTION}

\section{Spring cruise}

During this time, the prevailing southerly winds favoured a horizontal transport mainly to the interior of the Ría (main value $W_{x}=0.23 \mathrm{~m}^{2} \mathrm{~s}^{-1}$ ). The river flow varied from 10 to $23 \mathrm{~m}^{3} \mathrm{~s}^{-1}$, the mean value being $17 \pm 3 \mathrm{~m}^{3} \mathrm{~s}^{-1}$. A relatively sharp change is noticeable at the beginning of the cruise, with the maximum value on 20 May (19.8 $\mathrm{m}^{3} \mathrm{~s}^{-1}$ ). During this period river flow and rainfall data were coupled (Fig. 2). In order to establish the oceanic water behaviour compared with that of fresh waters, the isohaline of 35.5 was chosen as a reference, and waters saltier than this were considered as those poorly influenced by the river flow. 
On 19 May there was a vertically homogeneous surface layer (Fig. 4) which extended all over the surface of the Ría, piling fresh water up against its inner part. This situation generated a front between the Ría water bodies, separating downwelling forcing from positive circulation established at inner zones of the Ría. The halocline was placed at $10 \mathrm{~m}$ depth in the inner zone, reaching more than $20 \mathrm{~m}$ at outer stations. The oceanic water influence prevailed on the outer part of the Ría, becoming very noticeable in the inner bottom layers and reaching values above 35.7 in the outer bottom. The temperature distribution showed a surface gradient from $17.9^{\circ} \mathrm{C}$ at the head of the Ría to $16^{\circ} \mathrm{C}$ at Station 16 . A thick mixing layer caused great homogeneity in the surface and moved the thermocline to the bottom. A break in the continuity could be seen at Station 16, which produced the split of the minimum temperature in bottom layers $\left(14.7^{\circ} \mathrm{C}\right)$.

On 22 May (Fig. 4), the thermohaline situation changed because of the river flow increase and the relaxation of southerly winds. The intensity of the horizontal transport to the inner zones was reduced (Fig. 2). The rising of the 35.5 isohaline suggests the entrance of oceanic waters into inner zones. A middle-layer with homogeneous temperature $\left(15.8^{\circ} \mathrm{C}\right.$ $16.0^{\circ} \mathrm{C}$ ) and salinity (35.5-35.6) spread into the Ría. The displacement of the surface front to outer zones allowed fresh water to extend to the whole surface, with minimum values of 30.1 at Station 8 and 27.0 at Station 2. The intensified halocline rose to $5 \mathrm{~m}$. There was oceanic water removal in deeper outer zones. The temperature distribution showed a similar pattern. The thermocline rose to the same depth as the halocline, separating warm and less saline outgoing surface waters, with maximum temperatures of $17.7^{\circ} \mathrm{C}$ and $18.4^{\circ} \mathrm{C}$ corresponding to minimum salinities.

The strong southerly winds on 22 and 23 May changed to northerly ones on 24 and 25 May. On 26 May, the river flow descended to $12 \mathrm{~m}^{3} \mathrm{~s}^{-1}$. The thermohaline distribution for this day (Fig. 4) showed more homogeneity. The minimum salinity at Station 2 rose to 30.6. The halocline was restricted to inner zones, remaining at $5 \mathrm{~m}$. The 35.5 isohaline moved to outer and bottom zones, showing a low influence of oceanic waters and causing the falling of the maximum salinity (35.6). Salinity increased in outer surface layers, suggesting shelf water entrance as well as an increase in vertical mixing, placing the front in these zones. In the same manner, the mixing caused the reduction of the maximum surface temperature and the deepening of the vertical temperature gradient, mainly in outer zones.

Between 26 and 30 May the variable and weak winds had a low mean intensity to the north. From 26 May on, the river flow remained stable around 19 $\mathrm{m}^{3} \mathrm{~s}^{-1}$ (Fig. 2). On 30 May, a fresh surface water extension to outer zones can be seen (Fig. 4). The 35.1 isohaline, placed at $10 \mathrm{~m}$ on 26 May, was now around $15 \mathrm{~m}$. The entrance of 35.7 and $15.2^{\circ} \mathrm{C}$ oceanic water is also noticeable. The maximum temperature increased by two units $\left(19.5^{\circ} \mathrm{C}\right)$, as an effect of receiving more irradiation, and established the thermocline at $6 \mathrm{~m}$.

From 30 May on, there were weak south-easterly winds. In vertical profiles for 2 June (Fig. 4), fresh surface water spread more to outer stations. The 35.1 isohaline continued to descend, reaching more than $20 \mathrm{~m}$. There was a clear fall in salinity in the outer bottom zone, though the 35.5 isohaline still appeared. The increase in minimum temperature in the southern mouth $\left(15.7^{\circ} \mathrm{C}\right)$ confirms the removal of oceanic water. In the whole Ría there was an increase in surface temperature $\left(19.7^{\circ} \mathrm{C}\right)$, as well as a fall and thickening in the thermocline along the water column. The front was established at Station 16 in both distributions.

Southerly winds intensified from 2 June on. On 5 June, the surface salinity fell to 30.5 (Fig. 4). Though all the stations had not been sampled, a general fall in salinity was appreciable in the whole area. Oceanic waters moved to outer and deeper zones, decreasing the maximum salinity (35.6). The 35.1 isohaline fell to depths greater than $25 \mathrm{~m}$, though the halocline remained at $6 \mathrm{~m}$. The temperature range was similar to that of the previous sampling. The $18^{\circ} \mathrm{C}$ isotherm, at $12 \mathrm{~m}$ on 2 June, reached $18 \mathrm{~m}$ on 5 June, showing the tendency of the thermocline to occupy deeper layers.

During the cruise period, both the wind-driven horizontal transport and the river flow variations give the clues to explain the dynamic behaviour of the Ría. The situation on 19 May was characterised by wind-driven transport to the coast. A homogeneous surface layer was generated, which extended to inner zones, favouring the blocking of fresh water. A front separating positive (inner zones of the Ría) and negative (outer zones) circulation patterns was also generated. Wind relaxation on 22 May moved the front to outer stations, leading to a two-layer circulation development with a marked halocline and thermocline at $6 \mathrm{~m}$ depth. The removal of salty and cold deep-water was observed at stations next to the 
southern mouth. On the following days, the intense wind variation led to a horizontal transport into the Ría, causing vertical mixing in inner zones on 26 May and placing the front in outer zones of the Ría again. The Lérez River flow allowed the halocline to appear. The southerly winds weakened in the next few days, and northerly winds on 30 May led to the establishment of the thermocline and halocline in the whole Ría. A two-layered circulation developed and salty and cold waters entered outer and deeper zones. From 30 May to the end of the cruise, there were persistent southerly winds. The thermocline and halocline were still present on 2 June. Incoming surface shelf water introduced the front into the Ría, causing the deepening of the thermocline and the removal of cold and salty water. The intensification of southerly winds on 5 June led to a continuing fall in the thermocline and in the salinity all over the Ría.

\section{Autumn cruise}

Winds during this period generated bigger Ekman transports than those of the first cruise $\left(W_{x}=\right.$ $\left.0.38 \mathrm{~m}^{2} \mathrm{~s}^{-1}\right)$. The very intensive transport at the beginning fell sharply, showing negative values on the second sampling day and changing again to positive ones until the end of the cruise (Fig. 2).

The very intensive rainfall on the first few days fell to values of around $11.6 \mathrm{~mm}$ day $^{-1}$, with sharp variations. The river flow was rainfall coupled, varying from 8 to $42 \mathrm{~m}^{3} \mathrm{~s}^{-1}$ with a mean value of 22 $\pm 10 \mathrm{~m}^{3} \mathrm{~s}^{-1}$ (Fig. 2).

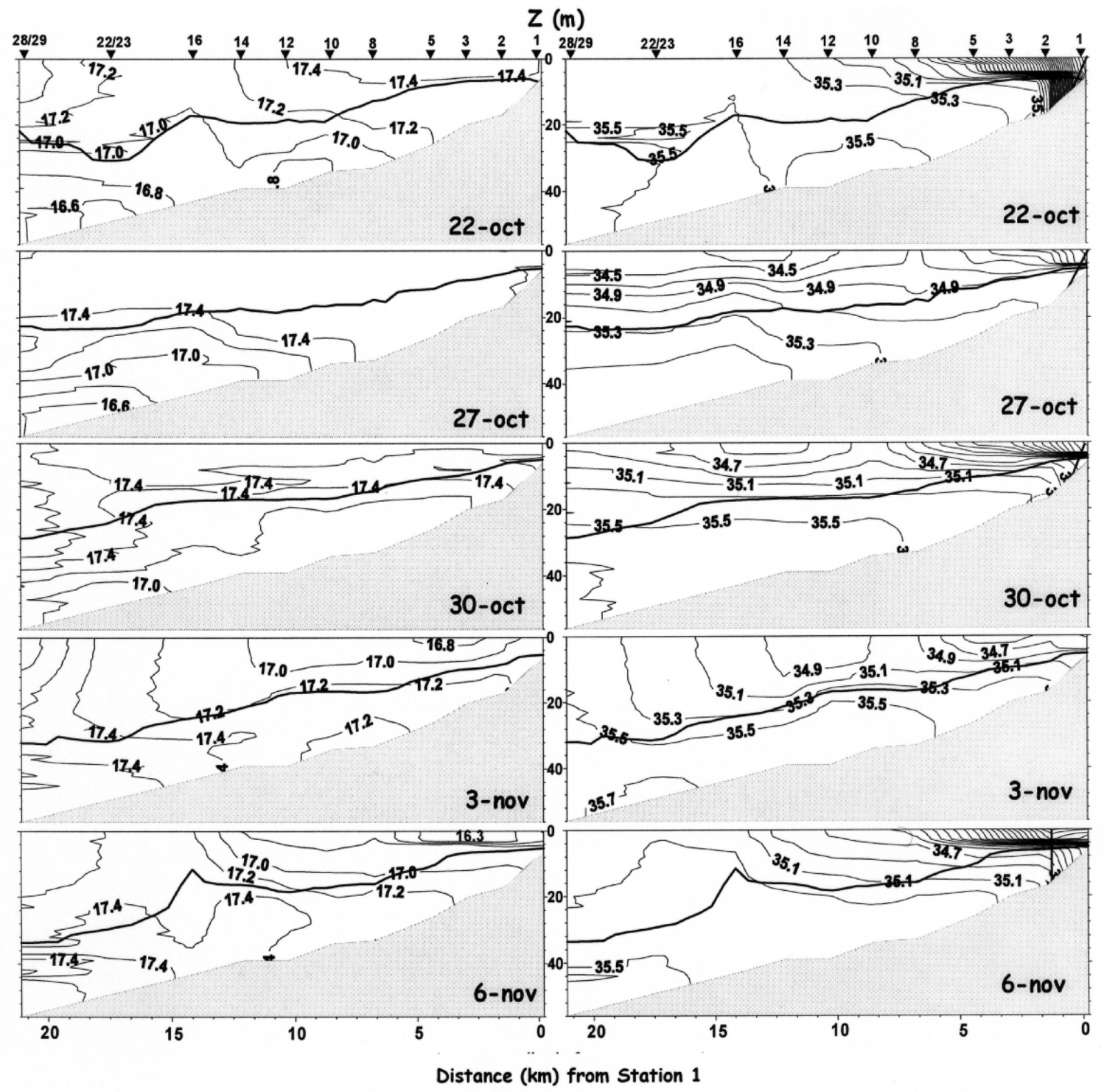

FIG. 5. - Thermohaline distributions for the autumn cruise across a longitudinal section parallel to the Ría axis. Left figures show temperature $\left({ }^{\circ} \mathrm{C}\right)$ stributions and right ones show salinity distributions. The black line shows the position of $Z$ for each sampling day. 
The strongest southerly winds $\left(W_{x}=1.5 \mathrm{~m}^{2} \mathrm{~s}^{-1}\right)$ blew on the days previous to 22 October (Fig. 2). The strong river flow generated the lowest minimum salinity (26.7) and fresh water was restricted to the inner stations (Fig. 5). There was a strong saline homogeneity in the rest of the Ría and in deeper layers until Station 3, showing the prevalence of oceanic waters. The vertical temperature gradient was very weak compared with that of the spring cruise, only being appreciable between Stations 12 and 5 . Warm incoming surface shelf water placed the thermohaline front at Station 14 , where the $16.8^{\circ} \mathrm{C}$ isotherm split.

Between 22 and 27 October there were prevailing weak south-easterly winds, giving values of $W_{x}$ $=0.37 \mathrm{~m}^{2} \mathrm{~s}^{-1}$ (Fig. 2). The river flow decreased and the minimum salinity increased to 33.2 (Fig. 5). A weak halocline was established in the whole Ría. The horizontal isohalines descended along the water column, while a vertical gradient extended to the whole area. The 35.3 isohaline was displaced to get more than $20 \mathrm{~m}$ deep, denoting an intensive vertical mixing all over it. The $17.4^{\circ} \mathrm{C}$ isotherm limited a highly mixed surface layer of saltier and colder oceanic waters. The minimum temperature $\left(16.5^{\circ} \mathrm{C}\right)$ was the same as for the previous sampling day.

On 30 October northerly winds prevailed $\left(W_{x}=\right.$ $-0.22 \mathrm{~m}^{2} \mathrm{~s}^{-1}$ ) (Fig. 2). The river flow increased, generating a minimum salinity of 31.6. The halocline, stronger in inner zones, was noticeable in the whole area due to rising isohalines with values higher than 35.2 (Fig. 5). The entrance of shelf waters into the Ría was confirmed by the increase in the maximum salinity (35.7), and also by the rising and penetration of the $17.4^{\circ} \mathrm{C}$ and $17.2{ }^{\circ} \mathrm{C}$ isothermes. The air temperature $\left(12.7^{\circ} \mathrm{C}\right)$, lower than that of the surface layers, gave the first signs of thermal inversion. The surface temperature was $17.3 \pm 0.2^{\circ} \mathrm{C}$.

From 1 November on, the winds over the shelf changed to southerly ones, with the highest intensity on 3 November (Fig. 2). The Lérez River flow fell abruptly causing an increase in the minimum salinity at the head of the Ría (34.4) and the attenuation of the halocline (Fig. 5). The deepening of the halocline from Station 12 to outer zones generated a homogeneous layer more than $20 \mathrm{~m}$ deep in this part of the Ría. The thermal inversion was intensified in the inner zone, reaching a $16.7^{\circ} \mathrm{C}$ minimum at the minimum salinity. The maximum temperature $\left(17.4^{\circ} \mathrm{C}\right)$ was distributed vertically next to the southern mouth.

Between 3 and 6 November southerly winds persisted, but gradually lost intensity (Fig. 2). The increase in the river flow generated a descent in the minimum salinity (30.7) on 6 November, intensifying the halocline at $5 \mathrm{~m}$, which extended to outer zones (Fig. 5). There was a sharp thickening between the 35.3 and 35.5 isohalines, the latter appearing only in the outer stations. The thermal inversion developed continuously, and the minimum temperature fell by $0.5^{\circ} \mathrm{C}$ compared with 3 November, supported by the salinity decrease. The maximum temperature was established at $30 \mathrm{~m}$. The entrance of colder and saltier shelf water established the front at Station 16 and stopped the fresh water from extending along the surface of the Ría.

The strong southerly winds at the beginning of the second cruise favoured the entrance of shelf water. Fresh water was piled up at the head of the Ría and strong vertical mixing was generated in the outer zone. On 27 October the two-layered circulation was established as a consequence of the decrease in downwelling, which displaced the front to outer zones. Nevertheless, the halocline was attenuated by the last period of strong vertical mixing and a $20 \mathrm{~m}$ deep homogeneous layer was generated. Between 27 October and 1 November, the weak northerly winds intensified the two-layered circulation pattern. Saline water entered deeper layers and fresh water extended to the outer zones on 30 October. The first signs of thermal inversion were appreciable. On 3 November southerly winds caused the entrance of outer surface water and the generation of a large mixing layer. The front was established in outer zones of the Ría, restricting positive estuarine circulation to the inner parts. Removal of bottom oceanic water was observed. From this date on, the continuous decrease in surface temperature led to an increase in the thermal inversion. On 6 November weak southerly winds prevailed and the river flow increased after a dry period. As a consequence of this, the two-layered circulation pattern was established and reached the middle part of the Ría. In the hypothetical case of an intensification of southerly-winds, the front would move to inner zones, piling the fresh water up to the head, as it happened on 22 October.

Even though cruises take place in such usually different seasons as spring and autumn, meteorological conditions involving sampling periods are not quite so different. At the beginning of both cruises Ekman transport showed positive values, being stronger for the autumn cruise. Then, some relaxation took place, leading the Ekman transport to negative values, but without allowing the development 
of upwelling within the Ría. This situation rapidly changed into downwelling forcing again at the end of both cruises. The Lérez River flow showed a sharp variation at the beginning of the autumn cruise, but then it settled at similar averaged values for the two periods. The water column was more stratified during the spring cruise, with a clear development of the thermocline and halocline towards the intermediate zones. During the autumn cruise the vertical gradients of both thermohaline properties were considerably weaker, leading to strong fluxes which enhanced the circulation pattern.

\section{BOX-MODEL OUTPUTS}

We wanted to estimate the effects of both shelf winds and river flow driving conditions on the dynamic behaviour of the Ría. In order to do this, we compared horizontal fluxes for each wall with the corresponding Ekman transport $\left(W_{x}\right)$ (considering a three-day delay, McLain et al., 1986, Rosón et $a l ., 1997)$ and river flow. Figure 6 shows the time evolution of ascent velocities and Ekman transport for each of the cruises. The horizontal fluxes are scaled down (Fig.6) by converting each one into spatially averaged vertical velocities. Thus, each of them is divided by the total surface area from the head of the Ría to the corresponding wall. Daily box-model outputs were averaged between two sampling days to obtain an estimation of an integrated situation within the Ría.
The correlations between averaged fluxes and Ekman transport were negative, the highest coefficients of determination $\left(\mathrm{r}^{2}\right)$ being those for W3 ( 0.47 for the spring cruise and 0.85 for the autumn cruise). The main effects of shelf-wind driving condition are noticeable in the outer zones of the Ría (Fig. 6). The ratios between Ekman transport and the averaged fluxes are $-6.8 \mathrm{~km}$ for the spring cruise and $-11.5 \mathrm{~km}$ for the autumn cruise, which are of a similar order to the width of W3. These results, especially for the autumn cruise, show that the horizontal fluxes estimated from the Ekman transport are very close to those predicted by the box-model and reproduce the water exchange between the Ría and the shelf very well.

When the same fluxes are compared with the river flow, the coefficient of determination is 0.41 for both cruises in W0, where the influence of the river flow is more relevant (Fig. 2 and 6). For the spring cruise the correlation was positive (river flow coefficient $=22.3$ ), that is, river flow was one of the driving forces for the horizontal fluxes of the inner walls, especially if the water bodies are well stratified within the Ría. Nevertheless, for the autumn cruise, the correlation was negative (river flow coefficient $=-11.9$ ). This unexpected correlation could be due to the weak stratification. The vertical density gradient for Box-1 in the autumn cruise $(0.72 \mathrm{~kg}$ $\mathrm{m}^{-3}$ ) was weaker than the one for the spring cruise $\left(1.45 \mathrm{~kg} \mathrm{~m}^{-3}\right)$. With low stratified water bodies, it is easier for the estuarine circulation pattern to change, even in inner parts of the Ría. During the autumn

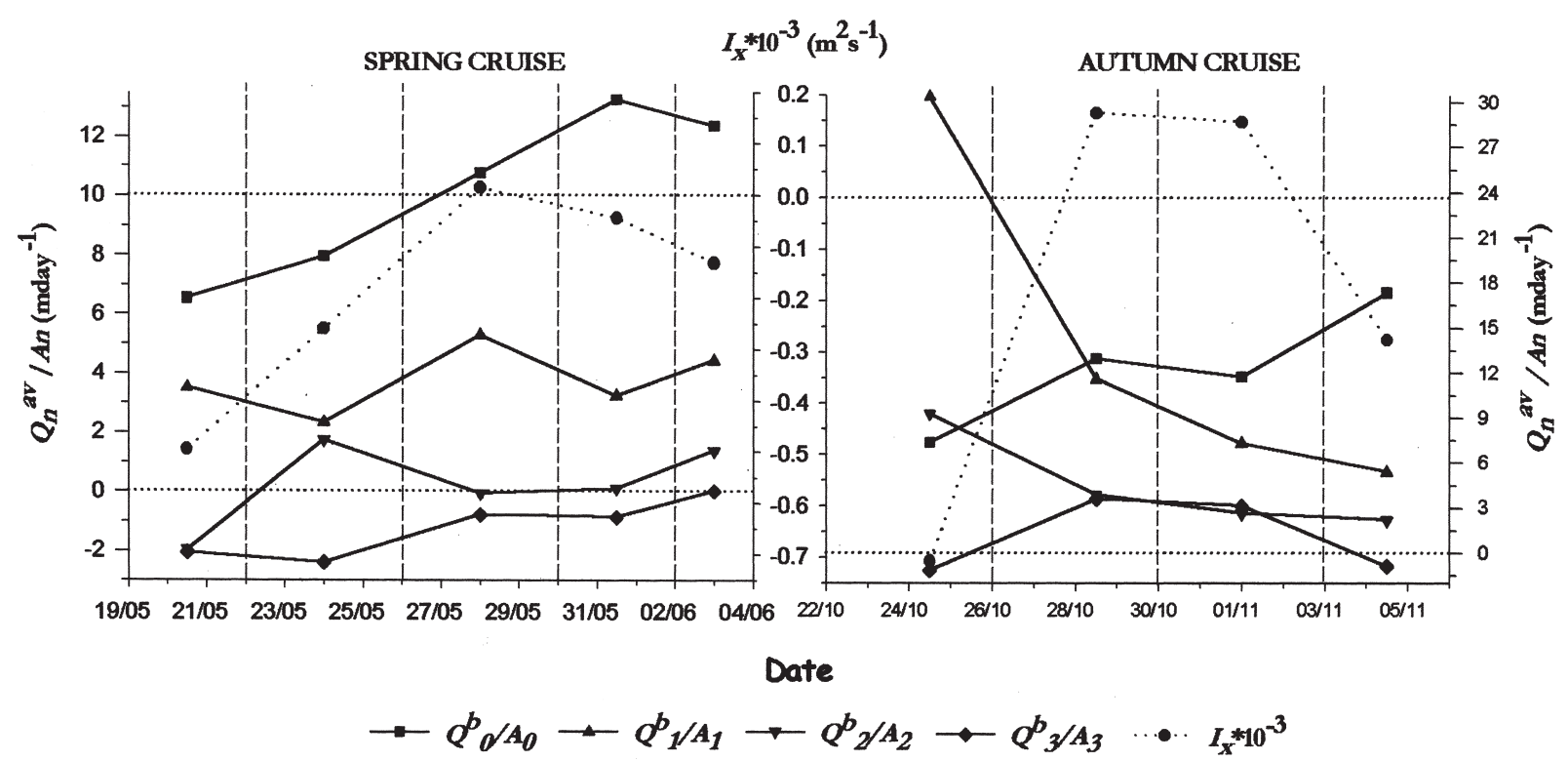

FIG. 6. - Time variation of spatially averaged velocities for both cruises. Averaged Upwelling Index is also represented. Each point is the average between two sampling days (vertical dashed lines). 
TABLE 1. - Multiple-correlation results. $\%$ river means the $\%$ of the total variance explained by river flow. $\mathrm{r}^{2}$ is the coefficient of determination. Wall width, surface area until the corresponding wall and mean depth in each box are also given.

\begin{tabular}{|c|c|c|c|c|c|c|c|c|c|}
\hline Wall & Width $(\mathrm{km})$ & Surface area $\left(\mathrm{km}^{2}\right)$ & Mean depth (m) & $r^{2}$ & $A_{1}$ & $A_{2}$ & $A_{3}$ & $A_{4}$ & $\%$ river \\
\hline 0 & 2.3 & 3.2 & 3.7 & 0.54 & 24 & 0.023 & -0.36 & -- & 38 \\
\hline 1 & 3.3 & 21.3 & 12.1 & 0.93 & 127 & 0.70 & 2.82 & -876 & 13 \\
\hline 2 & 4.9 & 69.2 & 20 & 0.75 & 165 & 4.61 & 4.12 & -2136 & 6 \\
\hline 3 & 11.5 & 175.3 & 25.9 & 0.8 & 364 & 19.2 & 1.96 & -7603 & 3 \\
\hline
\end{tabular}

$Q_{n}\left(\mathrm{~m}^{3} \mathrm{~s}^{-1}\right)=A_{1}$ river $+A_{2} I_{w}+A_{3} \Delta I_{w}+A_{4} \Delta \rho$

river in $\mathrm{m}^{3} \mathrm{~s}^{-1}, I_{w}$ in $\mathrm{m}^{2} \mathrm{~s}^{-1}, \Delta I_{w}$ in $\mathrm{m}^{2} \mathrm{~s}^{-1}, \Delta \rho$ in $\mathrm{kg} \mathrm{m}^{3}$

cruise, when the river inputs were relatively strong, southerly winds prevailed over the shelf creating a strong Ekman transport into the Ría. The lesser saline waters were confined to inner zones and the intensity of the horizontal fluxes in the inner walls was reduced. Lower river flow periods coincide with downwelling relaxation or upwelling events. The outgoing surface waters can extend to outer zones and horizontal fluxes are higher for the inner walls (Álvarez-Salgado, 1996). The combination of all these aspects may cause the observed negative correlation.

Multiple correlations were also made considering the data of both cruises together (Table 1). Horizontal fluxes in each wall $\left(Q_{n}\right)$ were the dependent variables and river flow $\left(Q_{r}\right)$, density gradient $(\Delta \rho)$, Upwelling Index $\left(I_{w}\right)$ and its time variability $\left(\Delta I_{w}\right)$ were the independent ones. Coefficients of determination were good for all walls, the highest one being that for W1. The Ekman transport influence grows towards the outer walls, as we expected from previous correlations. The river flow is more relevant in inner zones, where its coefficient achieved a proportionally higher weight (Table 1). The correlations were low for W0, perhaps because of the time renewal of Box- 0 . The water inflow in Box- 0 , in velocity terms (Fig. 6), varies from 6 to $18 \mathrm{~m} \mathrm{day}^{-1}$. Considering the mean depth of Box-0 (3.7 m), it yields a very low residence time (0.6-0.2 day), which is shorter than the frequency of sampling in both cruises. The time variability of Ekman transport $\left(\Delta I_{w}\right)$ seems to have a stronger effect in those zones in which the front was usually placed, because it separates different circulation patterns and varies in accordance with Ekman pumping. The negative value of this variable in W0 is probably due to the opposite effects of Ekman transport and river flow in horizontal fluxes of the inner walls for the autumn cruise. The density gradient is an estimation of the inertial movement of the water of the Ría under the effect of Ekman forcing. When there are relatively strong vertical density gradients in the water col- umn, the circulation of water bodies is slow. When the Ría is poorly stratified, the circulation pattern is more affected by shelf wind stress.

In order to estimate the spatial variability of vertical movements within the Ría, the vertical fluxes of each box were divided by the horizontal ones entering across the corresponding outer wall of the box (Table 2). For the autumn cruise, $75 \%$ of the horizontal flux crossing W1 rose in Box-1. For the spring cruise the relation varied within this range. During the autumn cruise, the Ría was poorly stratified and vertical fluxes were enhanced in inner parts in comparison with intermediate zones. Thus, hardly $10 \%$ of the horizontal flux crossing W2 in the autumn cruise rose in Box-2. Indeed it crossed W1 and rose in Box-1. This is corroborated by the high correlation between $Q_{22}$ and $Q_{1}\left(\mathrm{r}^{2}=0.99\right)$. Values of the ratio $Q_{z 2} / Q_{2}$ are high and variable for the spring cruise because the front was usually placed in Box2. When downwelling events occurred, downward flux in Box-2 was distributed between two lower horizontal fluxes. One of them entered inner zones to maintain the positive inner estuarine circulation pattern, the other one went out of the Ría. This results in higher values of $Q_{z 2}$ than $Q_{2}$. Under upwelling conditions, as Álvarez-Salgado et al. (1996) and Rosón et al. (1997) showed, the ratio takes values under unity $(\sim 0.70)$. Something similar occurred for the autumn cruise fluxes corresponding to Box-3, since the front was preferably sited in this box. Almost the whole flux downward in Box-3 went out of the Ría across W3 during the spring cruise.

TABLE 2. - Means and standard deviation of the ratios between vertical and horizontal fluxes are represented. $*$ An outlayer in the data group was removed due to a nearly zero value in $Q_{3}$.

\begin{tabular}{lll}
\hline & Spring Cruise & Autumn Cruise \\
\hline$Q_{z 1} / Q_{1}$ & $0.50 \pm 0.15$ & $0.75 \pm 0.23$ \\
$Q_{z 2} / Q_{2}$ & $3.14 \pm 10.17$ & $0.09 \pm 0.14$ \\
$Q_{z 3} / Q_{3}$ & $1.09 \pm 0.20^{*}$ & $2.02 \pm 1.75$ \\
\hline
\end{tabular}




\section{CONCLUSIONS}

A model similar to that of Rosón et al. (1997) has been applied here to the Ría de Pontevedra. The density and quality of sampling has been improved and we considered the thermal energy balance. Density gradient and time variability of Ekman transport were added as new driving forces, since recent studies demonstrated their importance in the dynamic behaviour of the Ría (Álvarez-Salgado et al., 1996; Rosón et al., 1999). It is important to note that during the two cruises downwelling conditions prevailed in the Ría. Previous works, usually with summer samplings, found the Rías affected by upwelling. Despite these anomalous conditions, outputs from the present box-model are more highly correlated than those obtained by Rosón et al. (1997). In outer parts of the Ría, almost $90 \%$ of the variability can be explained by Ekman transport and its time variability. The hard conditions prevailing during both cruises led to the appearance of a time variable front within the Ría, acting as a barrier between two opposite circulation regimes (ÁlvarezSalgado et al., 1997). From this front to the inner zones the Ría behaves dynamically as a typical positive estuary, while from the front to the outer zones the effect of an entering Ekman transport produces the inversion of the circulation pattern. The position of the front can be appreciated in box-model outputs, particularly when studying the coupling between horizontal fluxes and vertical ones for each zone of the Ría. High ratios between these fluxes with high standard deviations are obtained in those boxes in which the front is usually placed (Table 2). The effect of the stability of the water column is also noticeable. When water bodies are well stratified in the Ría, Ekman transport controls the outer zones, but if the water column is poorly stabilised, the associated shelf-wind transport effect reaches inner parts of the Ría, enhancing vertical fluxes in these zones. In this work the sampling interval was short (three to five days), which is adequate for most parts of the Ría. However, for the inner and shallow parts, the residence time (Fig. 6) is even shorter. The high correspondence between the model outputs and thermohaline data distributions shows the importance of using this kind of model as a tool in different oceanographic studies (Officer, 1980). Though models like this are useful and easy to apply in biogeochemical studies, a better comprehension of the hydrodynamic system may be necessary when searching for new answers in the behaviour of com- plex systems like the Rías Baixas. For this purpose it is important to create more friendly 3D numerical models in order to obtain better results with similar efforts as with 2D models (Nihoul, 1998).

\section{ACKNOWLEDGEMENTS}

The authors thank the crew of the oceanographic vessel Mytilus, and especially the physician Carlos Souto Torres, for their unconditional help in sampling. We also thank the Instituto Español de Oceanografía (IEO) for the meteorological station data in Ons Island, and the Instituto Nacional de Meteorología (INM) for supplying rainfall data. Support for this work came from CICYT project AMB95-1084. We thank FEUGA for including this study in the sub-programme "Dinámica y variabilidad termohalina" of the study "Ordenación integral do espacio marítimo-terrestre de Galicia".

\section{REFERENCES}

Álvarez-Salgado, X.A. - 1993. Mecanismos de transporte e balance bioxeoquímico do nitróxeno na Ría de Arousa. Doctoral Thesis. Santiago de Compostela University, Spain. 195 pp.

Álvarez-Salgado, X.A., G. Rosón, F.F. Pérez, F.G. Figueiras and Y. Pazos. - 1996. Nitrogen cycling in an estuarine upwelling system, the Ría de Arousa (NW Spain). I. Short-time-scale patterns of hydrodynamic and biogeochemical circulation. Mar. Ecol. Progr. Ser., 135: 259-273.

Álvarez-Salgado, X.A., G. Rosón, F.F. Pérez, F.G. Figueiras and A.F. Ríos. - 1996. Nitrogen cycling in an estuarine upwelling system, the Ría de Arousa (NW Spain). II. Spatial differences in the short-time-scale evolution of fluxes and net budgets. Mar. Ecol. Progr. Ser., 135: 275-288.

Álvarez-Salgado, X.A., M.D. Doval and F.F. Pérez. - 1997 Dissolved organic matter in shelf waters off the Ría de Vigo (NW Iberian upwelling system). J. Mar. Syst., 18 : 383-394 pp.

Bakun, A. - 1973. Coastal upwelling indices, west coast of North America, 1946-71, NOAA Tech. Rep. NMFS SSRF-671. US: Dep. of Commerce. 103 pp.

Bowden, K.F. - 1980. Physical factors: salinity, temperature, circulation and mixing processes. In: E. Olausson and I. Cato (eds.), Chemistry and Biochemistry of estuaries, pp. 37-70, Wiley \& Son.

Burden R.L. and J.D. Faires. - 1993. Numerical Analysis. Fifth Edition, 768 pp. PWS-KENT Publishing Company.

Fraga, F. - 1981. Upwelling of the Galician coast, Northwest Spain in Coastal and Estuarine Sciences 1. In: F.A. Richards (ed.), Coastal Upwelling, pp. 176-182. American Geophysical Union.

González-Quijano A., J.M. Cabanas, J.J. González and F. Schultze. - 1991. Datos químico-oceanográficos de la Ría de Pontevedra en invierno. Parte II. Infor. Téc. Inst. Esp. Oceanogr.

McClain C.R., C. Shenn-Yu, L.P. Atkinson, J.O. Blanton and F. de Castillejo. - 1986. Wind-driven upwelling in the vicinity of Cape Finisterre, Spain. J. Geophys. Res., 91: 8470-8486.

Mouriño C. and F. Fraga. - 1982. Hidrografía de la Ría de Vigo. 1976-1977. Influencia anormal del río Miño. Invest. Pesq., 46: 459-468.

Nihoul Jacques C.J. - 1998. Optimum complexity in ecohydrodynamic modelling: an ecosystem dynamics standpoint. J. Mar. Syst., 16: 3-5.

Officer, C.B. - 1980. Box Model Revisited. In: P. Hamilton and K.B. MacDonald (eds.), Estuarine and Wedland Processes with 
Emphasis on Modelling, pp. 65-114. Plenum Press.

Otto, L. - 1975. Oceanography of the Ria de Arousa (NW Spain). Konink. Meteor. International Mededelingen en Verlan, $\mathrm{n}^{\circ} 96$. $210 \mathrm{pp}$.

Pickard, G.L. and W.J. Emery. - 1990. Descriptive Physical Oceanography, An Introduction. Fifth Edition, 320 pp. Pergamon Press.

Prego, R. - 1988. Intercambio de sales nutrientes entre cuerpos de agua oceánicos seguido por métodos químicos. Doctoral Thesis. Santiago de Compostela University. 228 pp.

Prego R. and F. Fraga. - 1989. Condiciones hidrográficas previas a la purga de mar. Cuadernos del Área de Ciencias Mariñas, Seminario de Estudos Galegos, 4: 21-44.

Prego R., F. Fraga and A.F. Ríos. - 1990. Water interchange between the Ría of Vigo and the coastal shelf. Sci. Mar., 54: 95-100.

Pritchard, D.W. - 1951. The physical hydrography of estuaries and some applications to biological problems. Trans. $16^{\text {th }}$ North American Wildlife Conference. Wildlife Management Institute, Washington DC 368-376 pp.

Pritchard, D.W. - 1955. Estuarine Circulation Patterns. Proc. Am. Soc. Civil Eng., 81: 1-11.

Rios, A.F. - 1992. El fitoplancton en la Ría de Vigo y sus condiciones ambientales. Doctoral Thesis. Santiago de Compostela University. 416 pp.
Ríos A.F., M.A. Nombela, F.F. Pérez, G. Rosón and F. Fraga. 1992. Calculation of runoff to an estuary. Ría de Vigo. Sci. Mar., 56: 29 - 33 .

Ríos A.F., F.F. Pérez and F. Fraga. - 1992. Water masses in the upper and middle North Atlantic Ocean east of the Azores. Deep-Sea Res., 39: 645-658.

Rosón G., F.F. Pérez, X.A. Álvarez-Salgado and F.G. Figueiras. 1995. Variation of Both Thermohaline and Chemical Properties in an Estuarine Upwelling Ecosystem: Ria de Arousa. I. Time Evolution. Estuar. Coast. Shelf Sci., 41: 195-213.

Rosón G., X.A. Álvarez-Salgado and F.F. Pérez. - 1997. A Nonstationary Box Model to Determine Residual Fluxes in a Partially Mixed Estuary, Based on Both Thermohaline Properties: Application to the Ria de Arousa (NW Spain). Estuar. Coast. Shelf Sci., 44: 249 - 262.

Rosón G., X.A. Álvarez-Salgado and F.F. Pérez. - 1999. Carbon cycling in a large coastal embayment, affected by wind-driven upwelling: short-time-scale variability and spatial differences. Mar. Ecol. Progr. Ser., 176: 215-230.

Smith S.D. - 1988. Coefficients for sea surface wind stress, heat flux and wind profiles as a function of wind speed and temperature. J. Geophys. Res., 93: 467-472.

UNESCO. - 1981. Tenth report of the joint panel on oceanographic table and standards. Unesco Tech. Pap. in Mar. Sci., 36. 